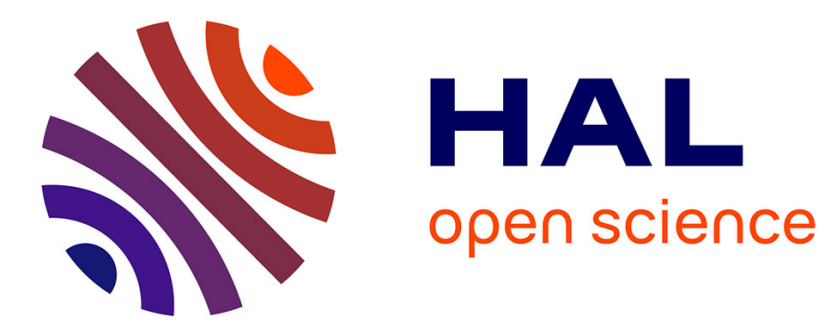

\title{
Tensile Behavior of Air Plasma Spray MCrAlY Coatings: Role of High Temperature Agings and Process Defects
}

Damien Texier, Clément Cadet, Thomas Straub, Chris Eberl, Vincent Maurel

\section{To cite this version:}

Damien Texier, Clément Cadet, Thomas Straub, Chris Eberl, Vincent Maurel. Tensile Behavior of Air Plasma Spray MCrAlY Coatings: Role of High Temperature Agings and Process Defects. Metallurgical and Materials Transactions A, 2020, 51, pp.2766-2777. 10.1007/s11661-020-05722-3 . hal-02517403

\section{HAL Id: hal-02517403 https://imt-mines-albi.hal.science/hal-02517403}

Submitted on 24 Mar 2020

HAL is a multi-disciplinary open access archive for the deposit and dissemination of scientific research documents, whether they are published or not. The documents may come from teaching and research institutions in France or abroad, or from public or private research centers.
L'archive ouverte pluridisciplinaire HAL, est destinée au dépôt et à la diffusion de documents scientifiques de niveau recherche, publiés ou non, émanant des établissements d'enseignement et de recherche français ou étrangers, des laboratoires publics ou privés. 


\title{
Tensile Behavior of Air Plasma Spray MCrAIY Coatings: Role of High Temperature Agings and Process Defects
}

\author{
DAMIEN TEXIER, CLÉMENT CADET, THOMAS STRAUB, CHRIS EBERL, \\ and VINCENT MAUREL
}

$\beta-\gamma$ MCrAlY coatings generally exhibit a brittle mechanical behavior below $600{ }^{\circ} \mathrm{C}$. When exposed at elevated temperatures, the microstructure of such coatings evolves, leading to an increasing content of $\gamma$ phase, i.e., the ductile phase, and a decreasing content of $\beta$ phase, i.e., the brittle phase. Therefore, the evolution of the mechanical properties of such environment-protective materials is worth of investigation. In the present study, a $\beta-\gamma \mathrm{NiCoCrAlY}$ coating was processed by air plasma spray (APS) technology. $150 \mu \mathrm{m}$-thin freestanding specimens were prepared then aged in an oxidative atmosphere at high temperatures $\left(950{ }^{\circ} \mathrm{C}\right.$ up to $\left.1150{ }^{\circ} \mathrm{C}\right)$ for different durations to simulate in-service degradation of the coatings. Microtensile testings were conducted at room temperature for all the aging variants and the mechanical properties of the aged specimens were found to evolve as follows: (i) an increase in both Young's modulus and tensile strength and a loss in ductility for aging temperatures below $1050{ }^{\circ} \mathrm{C}$, (ii) a decrease in Young's modulus and a gain in ductility for aging temperatures above $1050{ }^{\circ} \mathrm{C}$, and (iii) a significant scatter in mechanical properties for high temperature agings. The low ductility observed for high temperature agings was related to intruded oxides developing during the aging treatment, heterogeneously distributed in the volume of the coating. The gain in ductility was mainly attributed to the $\beta$-phase decrease, the loss in interconnection between $\beta$ phases compared to the as-received microstructure and a topological inversion of the $\beta-\gamma$ microstructure.

\section{INTRODUCTION}

NI-BASED superalloys used at high temperature need environment-protective coatings against high temperature oxidation and corrosion to limit detrimental impacts of the substrate oxidation on its long-term mechanical properties. ${ }^{[1-3]}$ Metallic coatings, such as MCrAlY overlay coatings or aluminide diffusion coatings, are alternative solutions to provide a substantial reservoir of $\mathrm{Al}$ or $\mathrm{Cr}$ necessary to promote the formation of a dense and very low-growth-rate oxide layer at high temperatures, i.e., $\alpha-\mathrm{Al}_{2} \mathrm{O}_{3}$ and/or $\quad \mathrm{Cr}_{2} \mathrm{O}_{3}$

DAMIEN TEXIER is with the Institut Clement Ader (ICA) UMR CNRS 5312, Université de Toulouse, CNRS, INSA, UPS, Mines Albi, ISAE-SUPAERO, Campus Jarlard, 81013 Albi Cedex 09, France. Contact e-mail: damien.texier@mines-albi.fr CLÉMENT CADET and VINCENT MAUREL are with Centre des Matériaux, Mines ParisTech - UMR CNRS 7633, BP 87, 91003 Evry Cedex, France. THOMAS STRAUB and CHRIS EBERL are with the Fraunhofer Institute for Mechanics of Materials IWM, 79108 Freiburg, Germany. depending on the operating temperature. ${ }^{[4-6]} \mathrm{MCrAlY}$ coatings ( $\mathrm{M}=\mathrm{Ni}, \mathrm{NiCo}, \mathrm{CoNi}$, etc. $)$ have demonstrated a very interesting trade-off between a low-cost process and excellent protection for industrial applications. Numerous line-of-sight and non-line-of-sight deposition processes were developed to manufacture coated components with complex geometries. Despite their environmental protection, coatings were reported to impair the mechanical integrity of the whole-coated components due to: (i) their brittle behavior below ductile-to-brittle transition temperature (DBTT) leading to premature cracks, (ii) their significant loss in mechanical strength but gain in ductility above the DBTT leading to non-bearing mechanical regions and thus additional weight, (iii) their interdiffusion with the Ni-based substrate affecting the mechanical properties of this latter structural material. ${ }^{[7-16]}$ The DBTT of MCrAlY coatings, ranging from $500{ }^{\circ} \mathrm{C}$ to $800{ }^{\circ} \mathrm{C}$, varies as a function of its composition with a high effect of the $\mathrm{Cr}$ content ${ }^{[8,11,13,17,18]}$ As a direct consequence, the low ductility of such coatings from room temperature up to $600{ }^{\circ} \mathrm{C}$ to $800{ }^{\circ} \mathrm{C}$ could be detrimental for coated Ni-based superalloys subjected to thermomechanical fatigue loading leading to tension in the brittle 
range of temperature of the coating. ${ }^{[19-21]}$ To obtain a robust identification of the mechanical response and the lifetime of coated materials, quantitative assessment of the mechanical properties of the overlay coating is needed.

Based on the coating thickness deposited on industrial components, i.e., tens of micrometers, two main approaches are developed in the literature to assess the macroscopic mechanical properties of the coating: (i) macromechanical testing of coated Ni-based superalloy substrates paired with inverse identification methods and (ii) micromechanical testing of freestanding coating specimens. Tensile testing of coated Ni-based superalloys with either overlaid or diffusion coatings has been conducted for decades ${ }^{[7-9,22,23]}$ on as-received and aged systems. High temperature agings of $\mathrm{Ni}$-based superalloys coated with $(\mathrm{Ni}, \mathrm{Pt}) \mathrm{Al}$ or $\gamma-\gamma^{\prime}$ diffusion coatings were demonstrated to considerably modify the mechanical properties of the coating, and especially its ductility. ${ }^{[22,23]}$ These studies have established that for (Ni,Pt)Al composition the $\beta$ to $\gamma^{\prime}$ phase transformation leads to an increase of the local ductility despite surface roughening induced by the so-called rumpling mechanism. ${ }^{[24]}$ A clear identification of local critical strain to failure is possible using in-situ optical microscope tensile testing to observe the first crack to appear and to assess strain fields by digital image correlation (DIC). DIC techniques are capable to quantitatively assess how the coating can accommodate the deformation of the ductile substrate but do not inform on the stress level within the coating (and the substrate). Based on a multi-layer analysis, inverse methods could enable to access to the coating mechanical behavior but are limited to thin substrate and coarse assumption: the gradient of composition and microstructure in the interdiffusion zone are ignored. ${ }^{[25,26]}$

Second, small-scale mechanical testing have shown an active interest in the characterization of thin coatings even at elevated temperatures. ${ }^{[13,27-32]}$ For overlay coating, because the chemical interactions between substrate and coating are by processing conditions much lower than diffusion coatings, samples made of freestanding coatings are very attractive..$^{[11,13,17,30,33]}$ Freestanding coating samples could be extracted from coated superalloys by electro-discharge machining (EDM) and/or micro-polishing using either manual or automatic precision jig. ${ }^{[27,31,34,35]}$ In parallel, specific devices were developed to prescribe mechanical loading on very small tensile specimens (cross-section being of hundreds and tens of microns in width and thickness, respectively). For micro-testing devices, one of the issue is to ascertain the quality of the mechanical state within the sample, i.e., the homogeneity of the strain field within the sample gauge length. Therefore, the use of digital image correlation (DIC) technique is highly needed to calculate effective strain maps from kinematic fields using a non-contact method. ${ }^{[36]}$

The present study aims to ascertain the influence of aging conditions on the room temperature mechanical properties of a typical freestanding MCrAlY coating. The proposed methodology is based on both stressstrain behavior and microstructure evolution analysis.
Fractographic analyses are also performed to identify fracture mechanisms related to microstructural features from pre-aged/pre-oxidized specimens.

\section{EXPERIMENTAL PROCEDURES}

\section{A. Material}

A NiCoCrAlY coating was deposited on a 304 stainless steel (SS) plate with dimensions of $50 \times 250 \mathrm{~mm}^{2}$ with an air plasma spray (APS) process. The nominal composition of the NiCoCrAlY powder (NI-191-4 coating from PRAXAIR ${ }^{[37]}$ ) is reported in Table I. No surface treatment of the 304 SS plate, e.g., grit/sand blasting, was purposely performed before coating APS deposition so that the delamination of the NiCoCrAlY coating naturally occurred at the SS plate/coating interface because of substantial stresses generated during the deposition process. This resulted in a 550 to $650 \mu \mathrm{m}$ thick freestanding coating with dimensions of $50 \times 250 \mathrm{~mm}^{2}$. Rectangular samples of $12 \times$ $50 \mathrm{~mm}^{2}$ were cut from the freestanding coating with a precision cutting machine. The samples were then subjected to two consecutive heat treatments under air to ensure an homogeneous $\beta-\gamma$ microstructure: 8 hours at $1080{ }^{\circ} \mathrm{C}$ then 20 hours at $870{ }^{\circ} \mathrm{C}$. This metallurgical state is further denoted "as-received" ("A.R.") microstructure in the present paper. Both sides of the freestanding coating samples were polished, using abrasive $\mathrm{SiC}$ papers from grade $\mathrm{P} 180$ to $\mathrm{P} 4000$, with the help of a precision jig. The samples were gritted to a thickness of $150 \mu \mathrm{m}$ with less than $2 \mu \mathrm{m}$ in thickness variation. The thin samples remain flat after polishing, attesting the low-residual stress level after projection, standard heat treatment, then specimen preparation. For experimental details on the sample preparation protocol, readers are referred to References 10 and 31 . Finally, dogbone-shape microtensile specimens were cut by electro-discharge machining (EDM) with the geometry reported in Figure 1(a). To reach a suitable roughness of the edges of the microtensile specimens $\left(R_{a} \leq 0.5 \mu \mathrm{m}\right)$, four EDM passes were performed with a $100 \mu \mathrm{m}$ diameter wire.

\section{B. High Temperature Aging}

Microtensile specimens were aged in air at different temperatures and for different durations to generate various microstructures of the coating and to investigate the evolution of the mechanical performances of the coating. All the high temperature aging conditions are reported in Table II. The temperature was verified with

Table I. Nominal Composition of the NI-191-4 Powder Used to Deposite the NiCoCrAIY Coating ${ }^{[37]}$ (in At. Pct)

\begin{tabular}{lccccc}
\hline Element & $\mathrm{Ni}$ & $\mathrm{Co}$ & $\mathrm{Cr}$ & $\mathrm{Al}$ & $\mathrm{Y}$ \\
\hline At. Pct & Balance & 23.0 & 17.0 & 12.5 & 0.55 \\
\hline
\end{tabular}




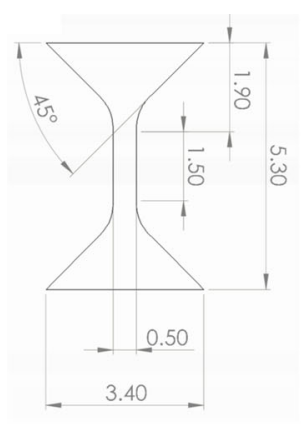

(a)

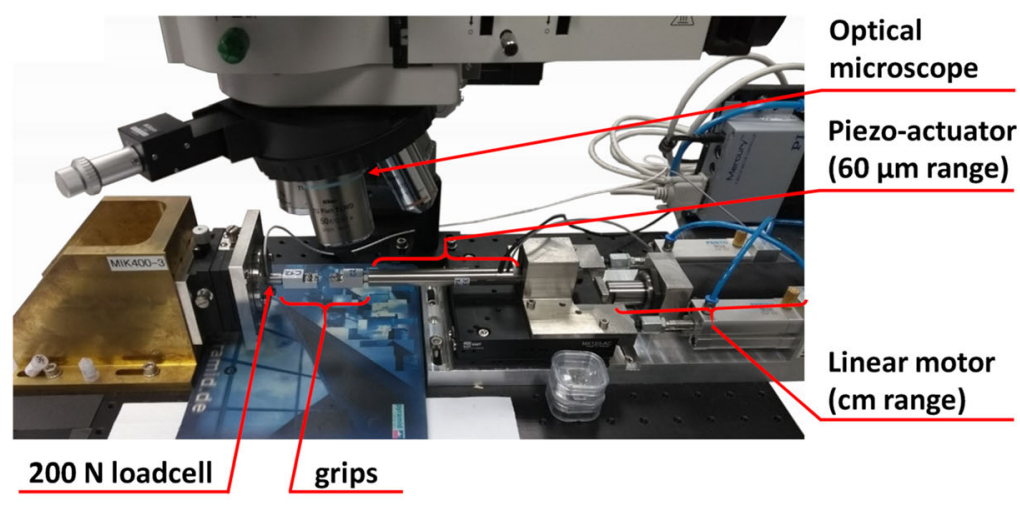

(b)

Fig. 1-(a) Geometry of the dogbone-shape microtensile specimen (dimensions in $\mathrm{mm}$ ), (b) experimental setup used to perform microtensile testing paired with digital image correlation (DIC) means.

Table II. High Temperature Aging Conditions

\begin{tabular}{lccl}
\hline A.R. & $950{ }^{\circ} \mathrm{C}$ & $1050{ }^{\circ} \mathrm{C}$ & $1150{ }^{\circ} \mathrm{C}$ \\
\hline $0 \mathrm{~h}$ & $50 \mathrm{~h}$ & $50 \mathrm{~h}$ & $50 \mathrm{~h}$ \\
& $200 \mathrm{~h}$ & $200 \mathrm{~h}$ & $139 \mathrm{~h}$ \\
& $500 \mathrm{~h}$ & $500 \mathrm{~h}$ & - \\
\hline
\end{tabular}

a K-type thermocouple for each of the eight aged conditions.

\section{Microtensile Testing at Room Temperature}

Tensile tests were carried out at room temperature on the microtensile specimens for all the aging conditions with the setup developed at the KIT (Karlsruhe, Germany $y^{[38,39]}$, and used in the Meso- and Micromechanics group of the Fraunhofer-IWM (Freiburg, Germany ${ }^{[40,41]}$ ) (see e.g. Figure 1(b)). The microtensile specimen was held in dovetail-shaped grips. Loading of the microtensile specimen was operated by a $60 \mu \mathrm{m}$ range piezo-actuator. Force along the loading direction was measured by a $200 \mathrm{~N}$ load-cell with a repeatability of $0.5 \mathrm{~N}$, i.e., 6.7 MPa owing to the specimen gage section. The tensile tests were conducted under an optical microscope mounted with a camera to obtain full-field kinematic fields via digital image correlation (DIC) technique. Without taking into account the magnification of the objective, a pixel on the image represents $5.5 \mu \mathrm{m}$ in the focal plane. Prior to tensile testing, the microtensile specimen was tight in the grips using downholders in the grips under a pre-load $2 \mathrm{~N}$, i.e., $30 \mathrm{MPa}$.

During the tensile test, the displacement speed operated with the short-range piezo-actuator is $1 \mu \mathrm{m} \mathrm{s}^{-1}$, i.e., an average strain rate of $7.10^{-4} \mathrm{~s}^{-1}$ for a microtensile specimen with a gage length of $1500 \mu \mathrm{m}$. The tests were continuously and monotonously running until the rupture of the specimen. Load and displacement were saved with a frequency of $10 \mathrm{~Hz}$, each measure consisting in the average of 300 values (acquisition running at a frequency of $3000 \mathrm{~Hz}$ ). One image per second was taken by the camera for local strain assessment. At least two tests per aging condition were performed.

DIC technique was used to assess full-field strain measurements within the specimen gage during the tensile test using a software developed by Eberl et al ${ }^{[36]}$ DIC is carried out using $20 \times 20 \mathrm{px}^{2}$ subset. Displacement field is obtained with a sub-pixel precision, and is linearly fitted in the direction of the axis to obtain the average (engineering) strain in the sample for each image. The stress-strain curves are then obtained by linking strain to the engineering stress, i.e., the load measured by the load-cell divided by the cross-section of the sample (deduced from width and thickness measured on each microtensile specimen after aging).

\section{Characterizations}

Cross-sectional observations of the NiCoCrAlY coatings were conducted for all the aging variants for investigation of the microstructure evolution. The samples were mounted in an epoxy resin and polished down to a $1 \mu \mathrm{m}$ diamond particles solution. The cross-sections were subsequently observed with a scanning electron microscope in a backscattered electron (BSE) mode (NanoNOVA FEG-SEM from Thermo Fisher scientific and JSM 7800F Prime FEG-SEM from JEOL). Five micrographs were taken for each aging condition with the same SEM-operating conditions (tension $=10 \mathrm{keV}$, probe current $=1.5 \mathrm{nA}$, working distance $=6 \mathrm{~mm}$ ) for image analyses using Fiji software ${ }^{[42]}$ to quantitatively document microstructural evolutions with the aging conditions. Fractographic observations were also performed in a backscaterred electron mode to identify features in the fractured region with difference in chemical composition.

\section{RESULTS}

\section{A. Microstructure Evolution of the Coating After Different Aging Conditions}

The A.R. microstructure is typical of sprayed materials, i.e., mainly consituted of melted and resolidified 


\section{Top view}
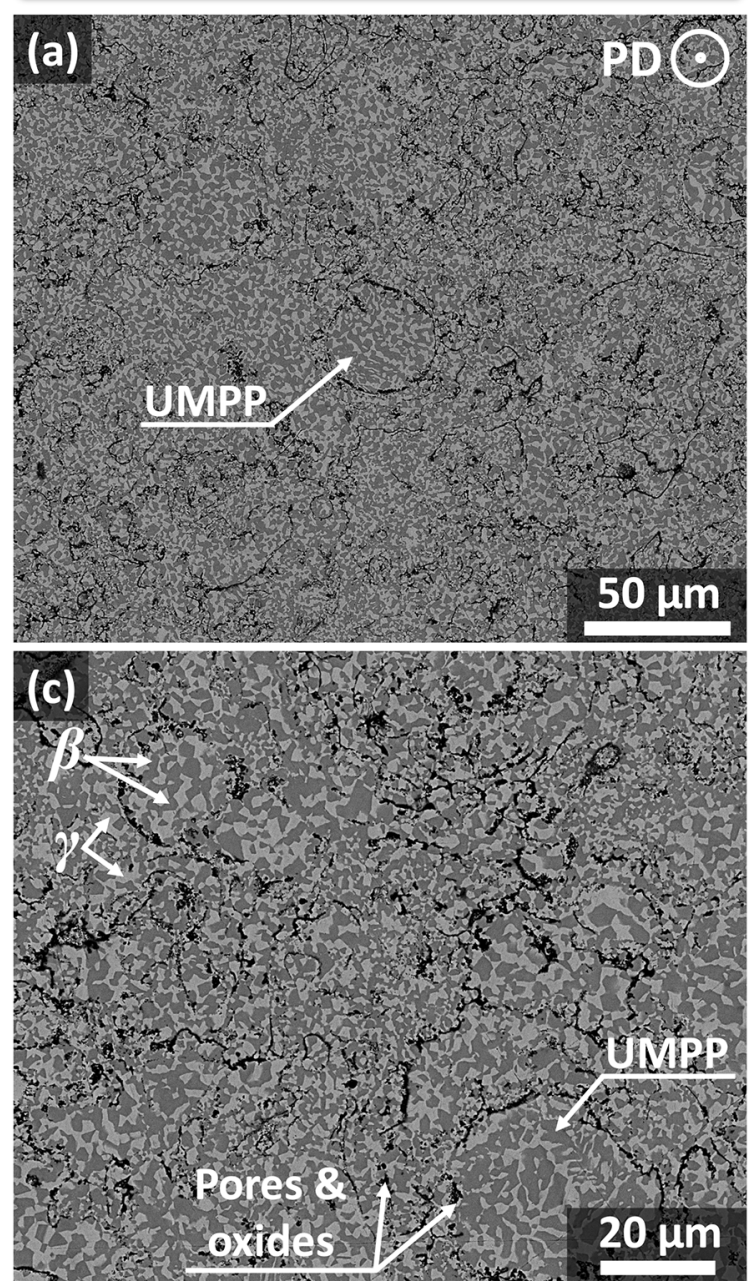

Cross-sectional view
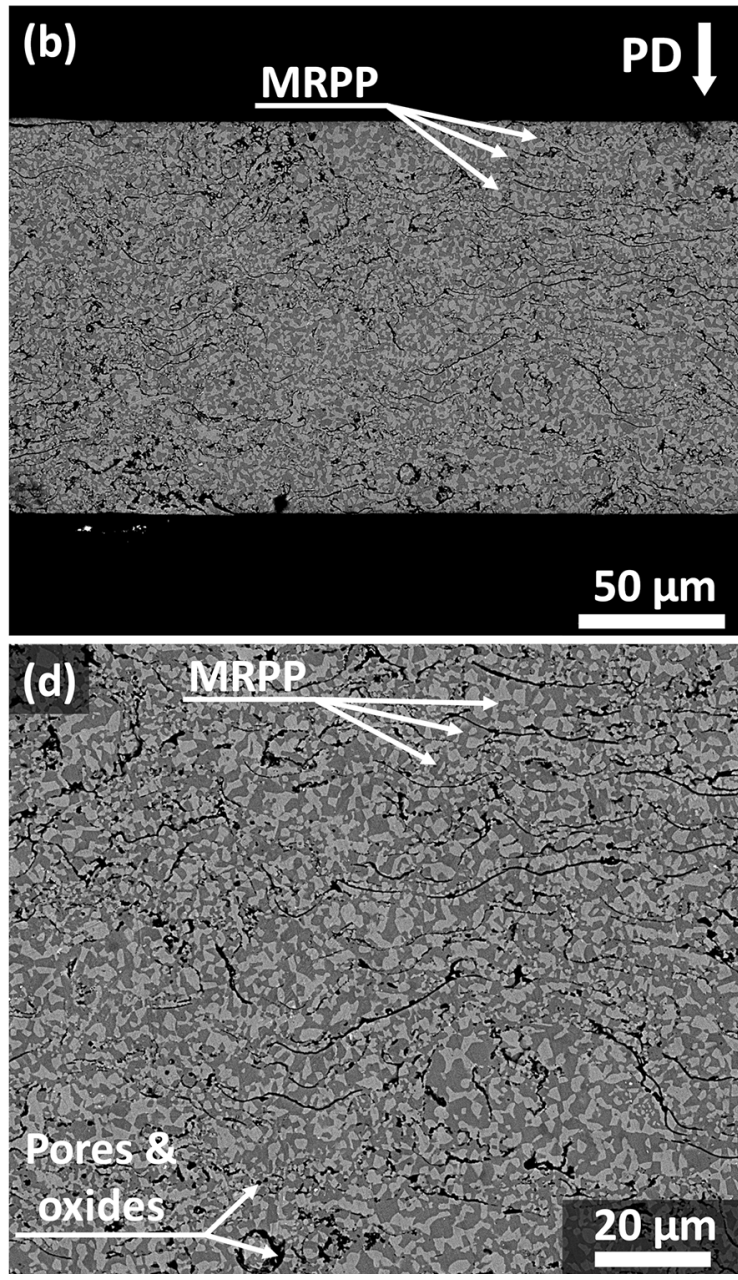

Fig. 2-Microstructure of the as-received A.R. NiCoCrAlY APS coating showing the microstructure in two observation planes: $(a)$ and $(c)$ Top surface observation with two magnifications, $(b)$ and $(d)$ cross-sectional observation with two magnifications.

powder particles (MRPP), un-melted powder particles (UMPP), pores, and dispersed alumina oxides, as shown in Figure 2. Top-surface and cross-sectional views were shown to illustrate the complex three-dimensional structure of the sprayed coating, with flat remelted particles normal to the spraying direction, and mostly rounded in the top view plane. The diameter of the rounded particles, surrounded by alumina oxides and pores, are found between 20 and $50 \mu \mathrm{m}$, similar to the size of the NI-191-4 powder specifications. The microstructure of the A.R. NiCoCrAlY coating consisted in a very fine $\beta-\gamma$ microstructure with a 59 pct $\beta$-41 pet $\gamma$ surface fraction proportion (obtained with image analyses on backscattered electron (BSE) images), see Figure 2. $\beta$ and $\gamma$ phases appear in dark and light gray on micrographs obtained in a BSE mode, respectively. Based on the high surface fraction of both $\beta$ and $\gamma$ phases, it is not straightforward to distinguish which phase was embedding the other one. Image analyses were conducted to quantitatively characterize the microstructure and assess the level of interconnectivity of the $\beta$-phase due to its significant brittleness at room temperature. The $\beta$-phase interconnectivity is defined as "the number of $\beta$ particles" divided by the total number of particles, i.e., $\beta$ phases, $\gamma$ phases, and oxides/pores. In the A.R. state, the $\beta$-phase interconnectivity was found lower than 1 pct, indicating that the $\beta$ phase is clearly embedding the $\gamma$ phase.

After aging, the $\beta-\gamma$ microstructure coarsened for all the aging temperatures, as depicted in Figure 3. Both phases coarsened with an equivalent diameter 2, 4, and 6 times larger for the $950{ }^{\circ} \mathrm{C}-500$ hours, $1050{ }^{\circ} \mathrm{C}-500$ hours, and $1150{ }^{\circ} \mathrm{C}-139$ hours aging conditions, respectively. Image analyses performed for all the aging variants aimed to assess the surface fraction of the $\beta$ and $\gamma$ phases in the core of the specimens, i.e., far from the oxidized surface. The $\beta$ phase fraction slightly decreases from 59 to 55 pct with the temperature increase from $950{ }^{\circ} \mathrm{C}$ to $1150^{\circ} \mathrm{C}$. The surface fraction of the $\beta$ and $\gamma$ phases is unchanged at a given temperature with the aging duration. 

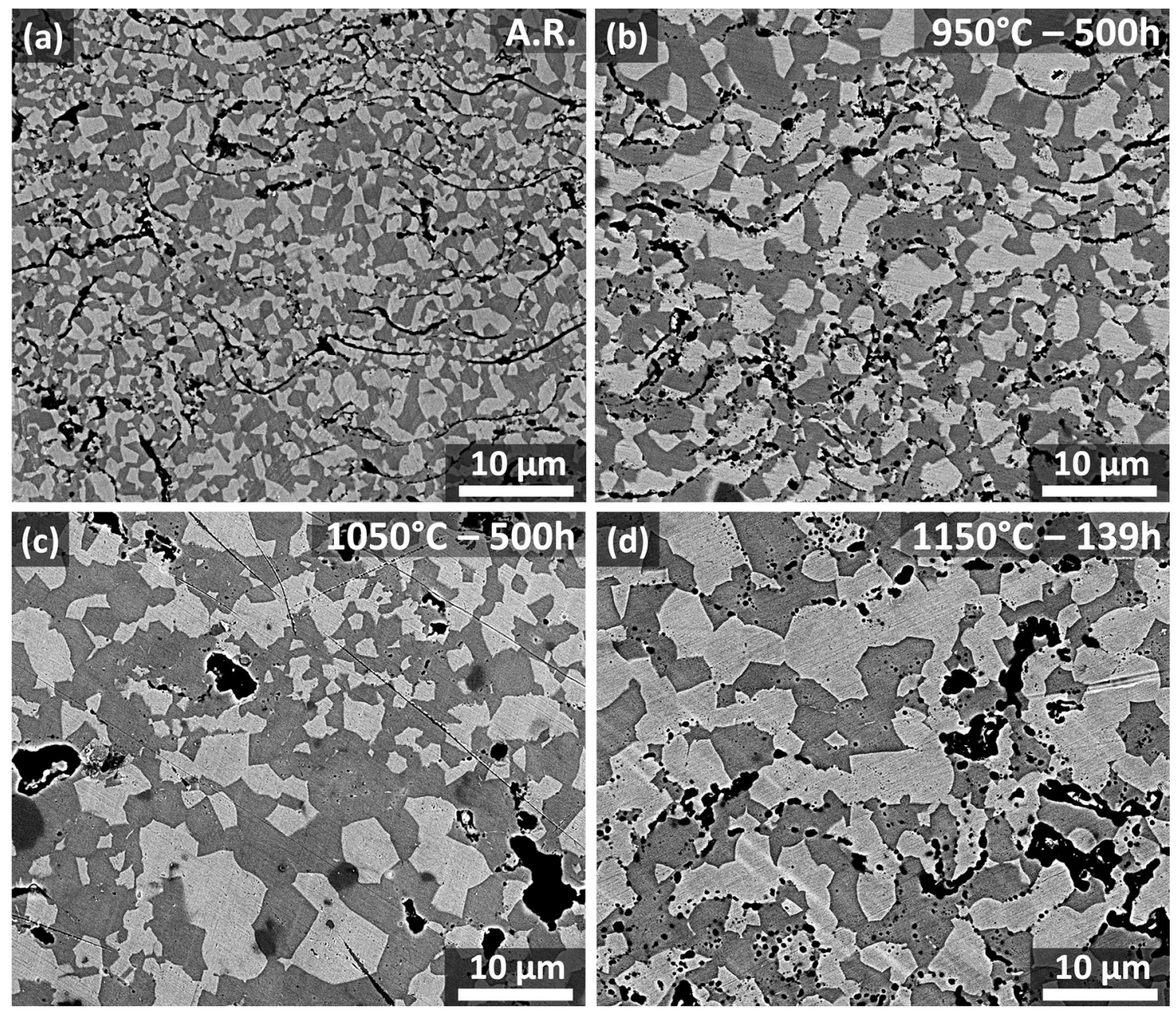

Fig. 3-Evolution of the $\beta-\gamma$ microstructure for different aging conditions from cross-sectional observation in backscattered electron mode: (a) A.R., (b) $950{ }^{\circ} \mathrm{C}-500 \mathrm{~h},(c) 1050{ }^{\circ} \mathrm{C}-500 \mathrm{~h}$, and $(d) 1150{ }^{\circ} \mathrm{C}-139 \mathrm{~h}$.

It is worth noting that the $\beta$ phase structure remained particularly interconnected up to $1050{ }^{\circ} \mathrm{C}$ (Figure 3(b) and (c)), but topological inversion started to occur for aging at $1150{ }^{\circ} \mathrm{C}$, i.e., the $\gamma$ was now embedding the $\beta$ phase (Figure 3(d)). The $\beta$-phase interconnectivity was measured from image analyses and reported in Figure 4(c)). The value of the $\beta$-phase interconnectivity increases with the temperature and a sharp transition at $1150{ }^{\circ} \mathrm{C}$, leading to values above 50 pct. At $1150{ }^{\circ} \mathrm{C}$, the number of connected $\beta$ phases and $\gamma$ phases is very similar. The $\gamma$ phase thus starts to embed the $\beta$ phase for aging conditions at this latter temperature.

Furthermore, agings at high temperature in air lead to external oxidation of the specimen, oxides being slightly different depending of the temperature range. $\mathrm{Cr}_{2} \mathrm{O}_{3}$ and $\mathrm{Al}_{2} \mathrm{O}_{3}$ developed below $1050{ }^{\circ} \mathrm{C}$ while $\mathrm{Al}_{2} \mathrm{O}_{3}$ exclusively developed at $1050{ }^{\circ} \mathrm{C}$ and above. The thickness of the external oxide layer was measured using image analysis on fracture surface and was reported in Figure 4(a). As expected from the literature, the growth of the external oxide layer is thermally activated.

A $\beta$-depleted layer developed beneath this oxide layer and is measured from cross-sectional observations in a BSE mode. The $\beta$-depleted layer, i.e., the $\gamma$ layer, increases with the temperature and the aging duration, as depicted in Figure 4(b). The presence of this $\gamma$ layer results from the gradient of chemical composition due to the selective oxidation at high temperature, progressively consuming the $\mathrm{Al}$ from the NiCoCrAlY coating to form the $\mathrm{Al}_{2} \mathrm{O}_{3}$ layer. It is worth noting that the thickness of the $\gamma$ layer can represent up to 14 pct of the specimen gage section for agings at $1150^{\circ} \mathrm{C}$.

\section{B. Tensile Behavior}

The tensile behavior for all the aging variants was characterized and several macroscopic tensile properties were summarized in Table III. Stress-strain behavior for two temperatures of aging were scrutinized, namely $950{ }^{\circ} \mathrm{C}$ in Figure 5(a) and $1150{ }^{\circ} \mathrm{C}$ in Figure 5(b) and compared to the A.R. condition for reference. The aging treatments were found to significantly modify the mechanical properties of the coating compared to the A.R. coating, i.e., the reference microstructure. While the tensile properties of the A.R. coating were very similar, a significant variability in tensile strength and ductility was noticed for all the aging variants. Variability in yield strength and ultimate tensile strength was 


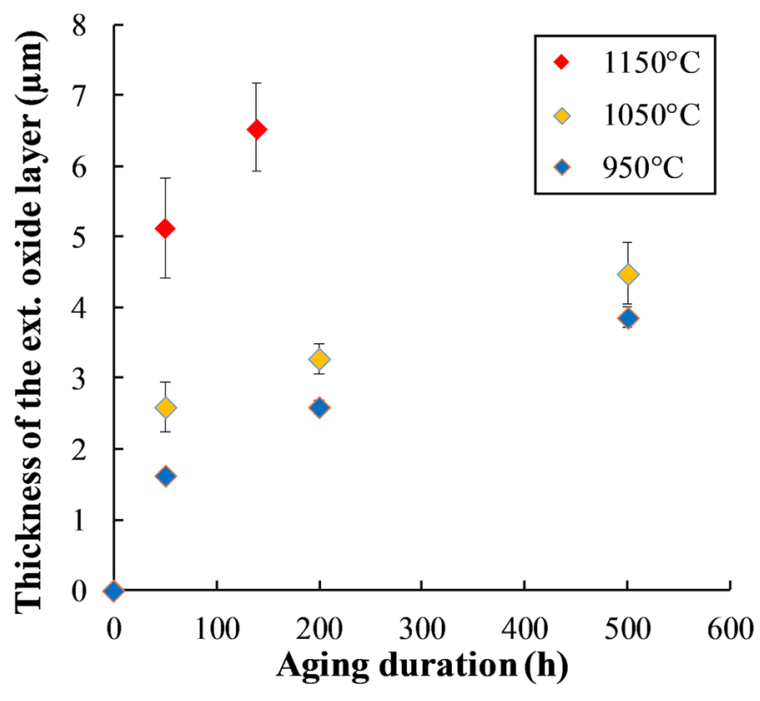

(a)

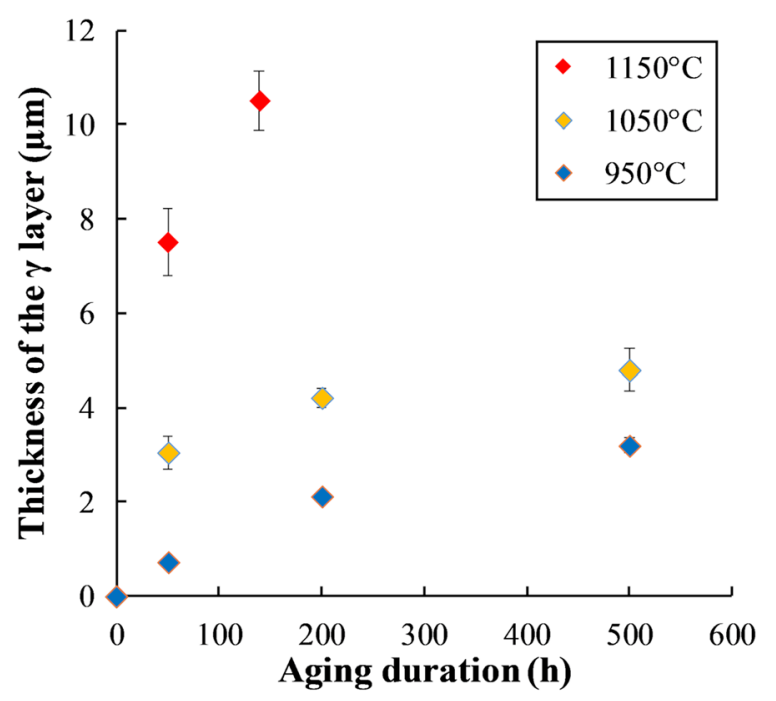

(b)

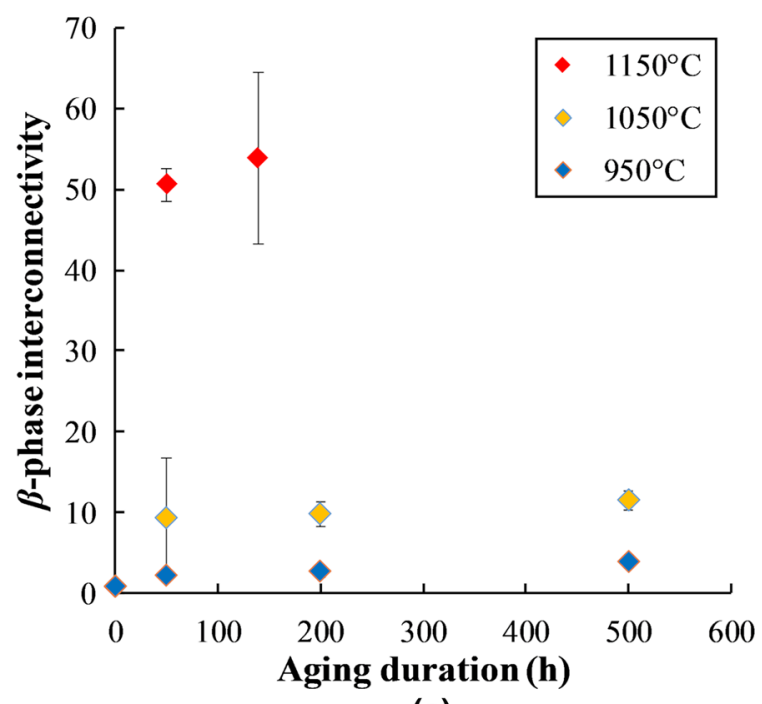

(c)
4 Fig. 4 Quantitative microstructural evolutions of the NiCoCrAlY coating for the different aging variants: $(a)$ Evolution of the external oxide layer, $(b)$ evolution of the $\gamma$ layer beneath the external oxide layer, and $(c)$ evolution of the $\beta$-phase interconnectivity.

found for the three aging temperatures but variability in strain-to-failure (STF) was mainly reported for agings at $1150{ }^{\circ} \mathrm{C}$. This variability is accompanied by a significant increase of the maximal strain-to-failure for agings at $1150{ }^{\circ} \mathrm{C}$.

In the A.R. condition, the behavior of both the tested samples is very close to each other. The ductility is below $0.6 \mathrm{pct}$, which is a rather low value at room temperature but typical of MCrAlY coatings. ${ }^{[8,11,13,17,18]}$ Because of this low ductility, the material behavior is close to an elastic-brittle behavior. However, the identification of 0.05 pct. offset yield strength $\left(Y S_{0.05 p c t}\right)$ was possible and led to $600 \mathrm{MPa}$ (Figure 5(a)). Aging at $950{ }^{\circ} \mathrm{C}$ for 50 to 500 hours led to a systematic increase of the Young's modulus, the $Y S_{0.05 p c t}$, and the ultimate tensile strength (UTS). However, some variability in strain-to-failure (STF) was found for exposures at $950{ }^{\circ} \mathrm{C}$ and $1050{ }^{\circ} \mathrm{C}$ (Figure 5(a) and Table III). For agings at $950{ }^{\circ} \mathrm{C}$, the maximal ductility noticed was similar to the as-received ductility. It is worth mentioning that few specimens exhibit slightly improved ductility for agings at $1050{ }^{\circ} \mathrm{C}$ for 200 and 500 hours. Aging at $1150{ }^{\circ} \mathrm{C}$ for 50 to 139 hours led to most of specimens to a decrease of the Young's modulus and an increase of the apparent ductility (Figure 5(b) and (d) and Table III). Interestingly, the variability in strain-to-failure and ultimate tensile strength increased with the exposure temperature and duration whereas the variability in yield strength was found similar for all the temperatures. The reasons of such variability in strain-to-failure will be further explained. The mechanical testing has led to following major trends :

- increase in Young's modulus and tensile strength $\left(Y S_{0.05 p c t}\right.$ and UTS) and loss in ductility for agings at 950 and $1050{ }^{\circ} \mathrm{C}$;

- decrease in Young's modulus and gain in ductility for agings at $1150^{\circ} \mathrm{C}$;

- increase of the variability in mechanical properties for agings at $1150{ }^{\circ} \mathrm{C}$.

A summary of the evolution of the macroscopic mechanical properties, i.e., the Young's modulus, the $Y S_{0.05 p c t}$, the UTS and STF, of the aged coatings is illustrated as a function of the aging temperature in Figure 6. Error bars representing the measurement precision in this experimental work, i.e., the resolution and repeatability of the load-cell, the optical means to measure both the thickness and the width of the specimens, the strain resolution using DIC, were 
Table III. Mechanical Performance vs Fraction of Intruded Oxide Measured on the Fracture Surface for All the Tested Specimens

\begin{tabular}{|c|c|c|c|c|c|c|c|}
\hline Temperature $\left({ }^{\circ} \mathrm{C}\right)$ & Time (h) & Young's Mod. (GPa) & $\mathrm{YS}_{0.05 p c t}(\mathrm{MPa})$ & $\mathrm{YS}_{0.2 p c t}(\mathrm{MPa})$ & UTS (MPa) & STF ( pct) & $F_{\text {ox.int. }}(\mathrm{pct})$ \\
\hline "A.R." & - & 112 & 565 & - & 601 & 0.62 & - \\
\hline "A.R." & - & 123 & 577 & - & 607 & 0.59 & - \\
\hline 950 & 50 & 177 & 638 & - & 732 & 0.59 & 2.2 \\
\hline 950 & 50 & 172 & 635 & 669 & - & 0.54 & 5.9 \\
\hline 950 & 200 & 182 & 612 & 722 & 742 & 0.69 & 2.6 \\
\hline 950 & 200 & 263 & 576 & - & 679 & 0.43 & 28.4 \\
\hline 950 & 200 & 160 & 632 & - & 726 & 0.61 & 29.0 \\
\hline 950 & 500 & 211 & 554 & 695 & 709 & 0.58 & 7.1 \\
\hline 950 & 500 & 152 & 663 & - & 680 & 0.60 & 19.0 \\
\hline 950 & 500 & 167 & 639 & - & 656 & 0.57 & 19.2 \\
\hline 1050 & 50 & 173 & 540 & - & 560 & 0.40 & 49.2 \\
\hline 1050 & 50 & 199 & 533 & 638 & 654 & 0.62 & 13.5 \\
\hline 1050 & 50 & 214 & 510 & - & 612 & 0.46 & 42.44 \\
\hline 1050 & 200 & 246 & 508 & 558 & 562 & 0.67 & 19.5 \\
\hline 1050 & 200 & 199 & 470 & 585 & 591 & 0.58 & 30.6 \\
\hline 1050 & 200 & 204 & 499 & 595 & 642 & 0.8 & 1.5 \\
\hline 1050 & 500 & 211 & 527 & 589 & 605 & 0.63 & 23.1 \\
\hline 1050 & 500 & 189 & 507 & 579 & 595 & 0.70 & 39.6 \\
\hline 1050 & 500 & 161 & 456 & - & 514 & 0.38 & 39.8 \\
\hline 1150 & 50 & 105 & 519 & - & 570 & 0.76 & 6.7 \\
\hline 1150 & 50 & 121 & 441 & 551 & 647 & 1.2 & 13.8 \\
\hline 1150 & 50 & 68 & 508 & 582 & 688 & 1.6 & 1.2 \\
\hline 1150 & 139 & 81 & 438 & 553 & 712 & 3.3 & 3.4 \\
\hline 1150 & 139 & 132 & 444 & - & 525 & 0.63 & 17.2 \\
\hline 1150 & 139 & 137 & 484 & 536 & 591 & 1.4 & 16.6 \\
\hline
\end{tabular}

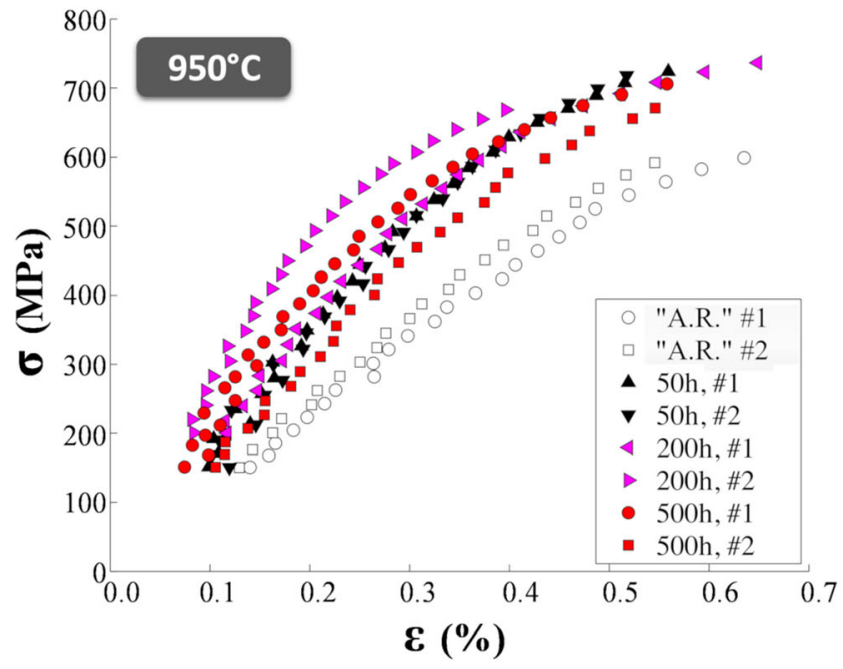

(a)

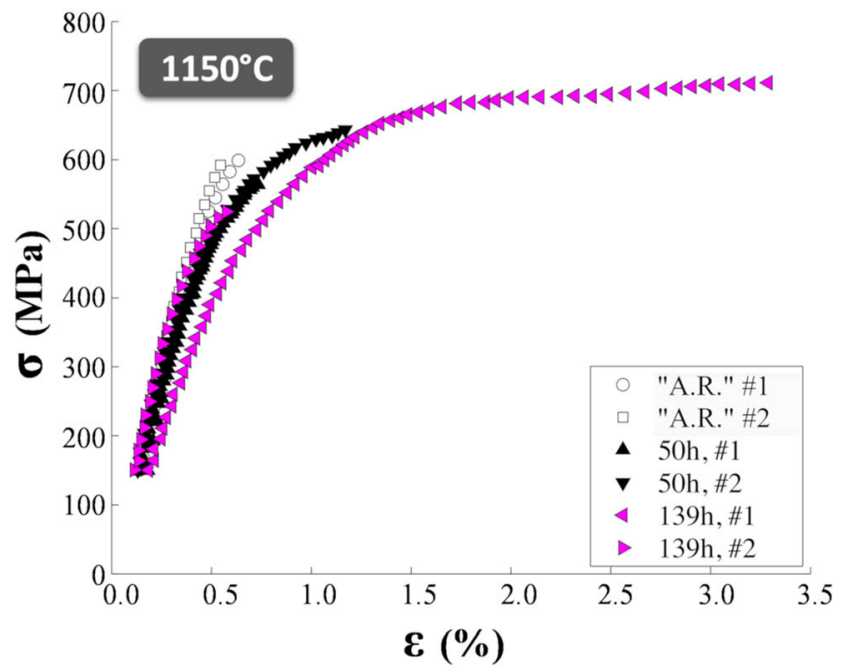

(b)

Fig. 5-Evolution of the tensile behavior of aged coating specimens compared to A.R. coating specimens: $(a)$ aging time at $950{ }^{\circ} \mathrm{C},(b)$ aging time at $1150{ }^{\circ} \mathrm{C}$.

reported in Figure 6. Owing to the measurement precision, the variability in the measured mechanical properties is a material issue. A careful analysis of the influence of aging on both microstructure evolution and failure mechanism is addressed in the following sections to explain the variability in mechanical response for a given aging treatment.

\section{Fractography}

Fracture surfaces of all the microtensile-tested specimens were observed in a backscattered electron mode. Because the highest scatter in behavior was observed at $1150{ }^{\circ} \mathrm{C}$ for 139 hours, a particular attention was paid on this condition (Figure 7). First specimen, reported as "139 hours \#1" in Figure 5(b), corresponds to a "high 


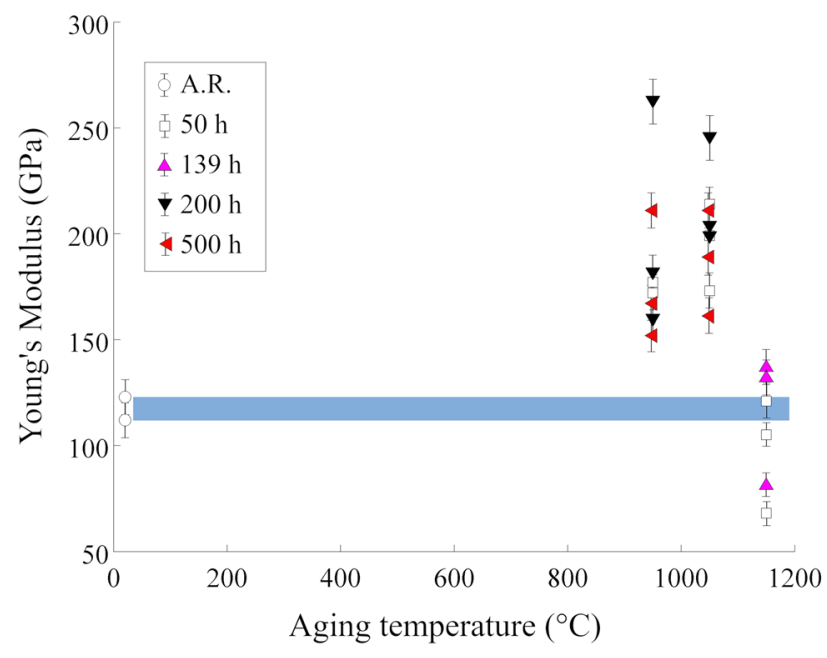

(a)

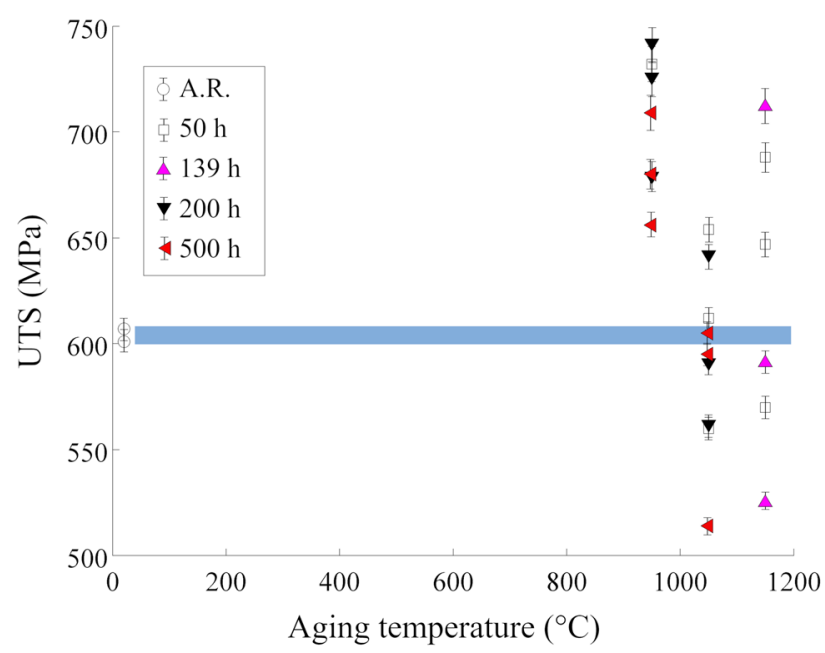

(c)

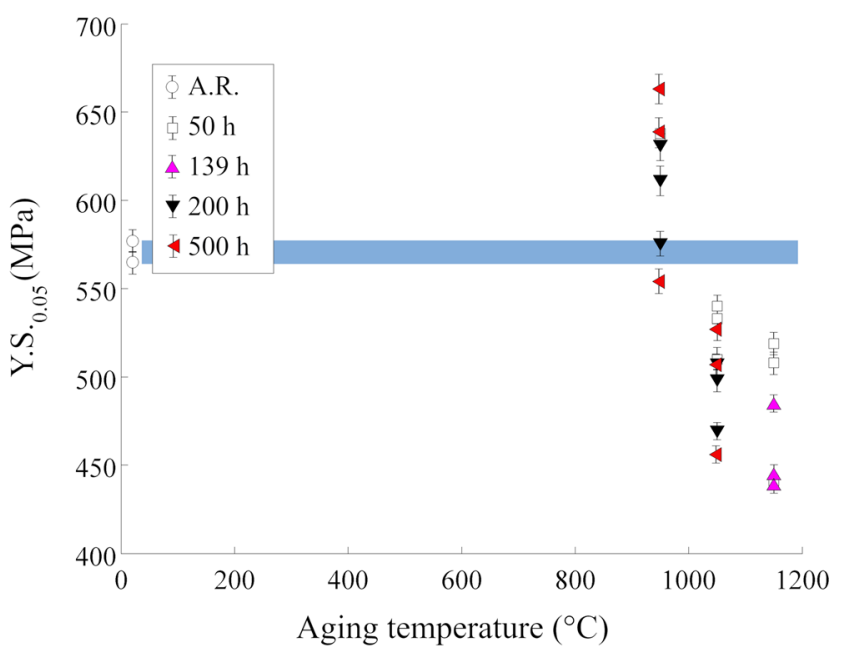

(b)

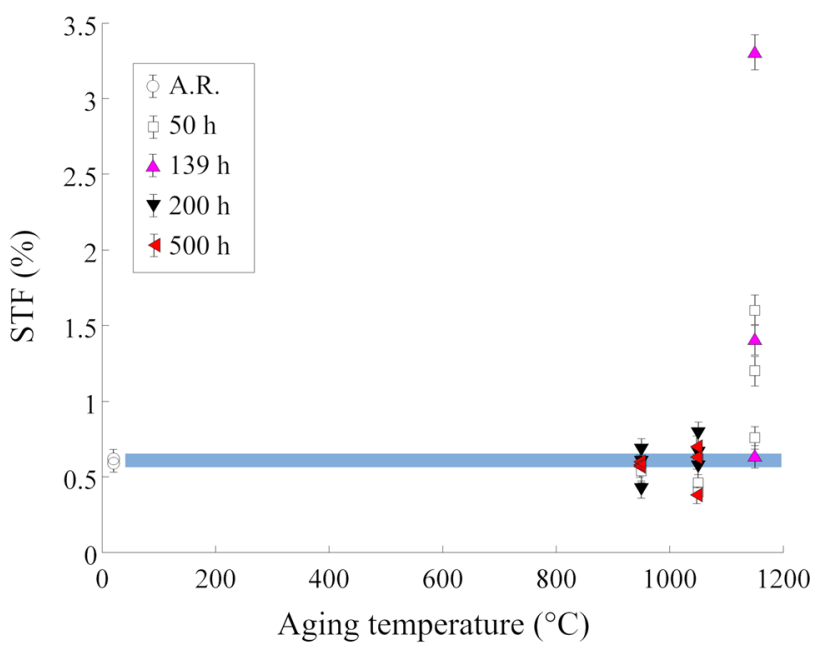

(d)

Fig. 6-Evolution of the macroscopic tensile properties of aged coating specimens as a function of the aging temperature and compared to A.R. coating specimens: $(a)$ Young's modulus, $(b) 0.05$ pct offset yield strength $\left(Y S_{0.05 p c t}\right)$, $(c)$ ultimate tensile strength (UTS), and $(d)$ strain-to-failure (STF). Blue horizontal boxes in all the figures correspond to the tensile properties of the A.R. coating for comparison (Color figure online).

strength/high ductility/low defects" specimen. It is worth noting that the fracture surface shown in Figure 7(a) depicted a homogeneous gray level on the whole fracture surface. Cleaved grains surrounded by regions with dimples and pores were found on the whole fracture surface (Figure 7(b)). Such fracture features clearly demonstrated the complex brittle ( $\beta$ phase) plus ductile $(\gamma$ phase) fracture of the "high strength/high ductility/low defects" specimen. The size and spatial distribution of cleaved $\beta$ grains and $\gamma$ grains with dimples are consistent with the microstructural evolutions noticed after agings.

In contrast, dark gray regions were noticed on the fracture surface of the "low strength/low ductility/high defects" specimens, corresponding to oxide intrusion (Figure 7(c)). EDX analyses were used on the fracture surface to identify the chemical nature of the oxides for the different aging temperatures. Similarly to the observations in the Section III-A, a mixture of $\mathrm{Cr}_{2} \mathrm{O}_{3}$ and
$\mathrm{Al}_{2} \mathrm{O}_{3}$ was found to develop at $950{ }^{\circ} \mathrm{C}$ as intruded oxides while $\mathrm{Al}_{2} \mathrm{O}_{3}$ solely grew at $1050{ }^{\circ} \mathrm{C}$ and above. The intruded oxide, i.e., oxides developing in the volume of the NiCoCrAlY specimen, was shown to occupy in some cases a significant fraction of the fracture surface. Image processing techniques using Fiji software ${ }^{[42]}$ has enabled to evaluate the surface fraction of oxide intrusion $\left(F_{\text {ox.int. }}\right)$ for all the tested specimens, see Table III. As shown in Figure 7, oxide intrusion was demonstrated to strongly impair the mechanical properties by string limitation of the ductility of the aged coatings but also led to significant changes in fracture mechanisms. As shown in Figure 7(d), fractured regions in the vicinity of intruded oxides presented a relatively smooth aspect with small dimples. This region corresponds to the ductile fracture of a continuous $\gamma$ layer surrounding the intruded oxides, i.e., the $\beta$-depleted layer but also oxide/ metal debonding. Far from those intruded oxides, dimples and layered structures corresponding to the 

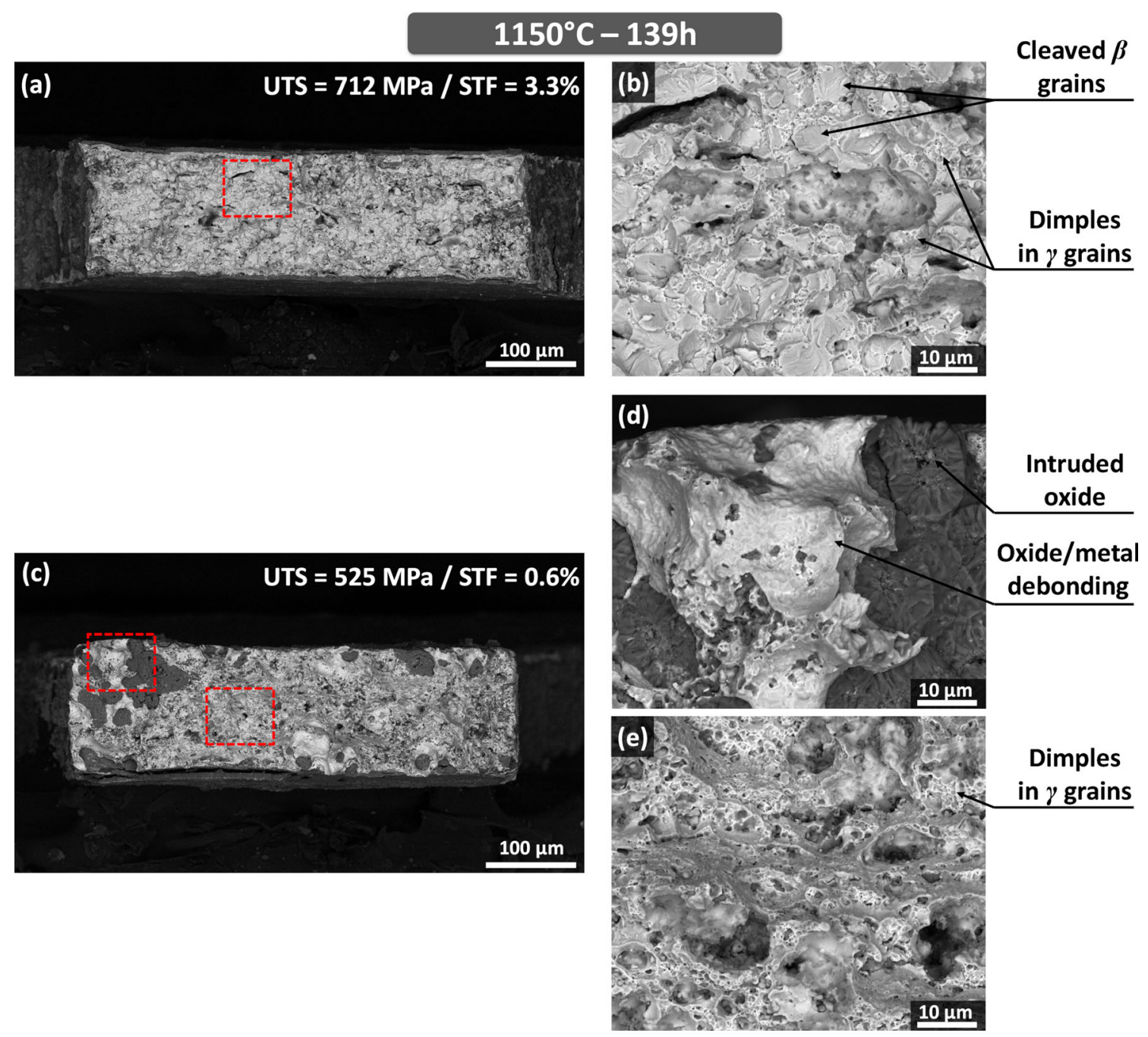

Fig. 7-Fracture surfaces observed in backscattered electron mode showing the relation between: $(a)$ and $(b)$ a high ductility/high strength/low oxide intrusion specimen, and (c) to (e) a low ductility/low strength/high oxide intrusion specimen. (b), (d) and (e) correspond to magnified regions highlighted by red dashed boxes in low magnification fractographs (Color figure online).

melted and resolidified powder particles (MRPP) were noticed in Figure 7(e). Such features were different to the fracture features observed in sound regions for the "high strength/high ductility/low defects" specimen Figure 7(b). The fracture mechanisms related to the aged microstructures will be further discussed in Section IV.

\section{Defects Analysis}

Oxide intrusion present on the fracture surface systematically led to "low strength/low ductility/high defects" of the aged material for monotonic tensile testing loading. However, the occurrence of these defects and their significant proportions on the gage section, i.e., on a $500 \times 150 \mu \mathrm{m}^{2}$ section, were not systematic. Fracture surface observations demonstrated that oxide intrusion could cross the entire thickness of the specimens. Therefore, a careful analysis of the distribution of the oxide intrusion in the specimen volume is mandatory to explain the variability in tensile properties aforementioned. A large $\mathrm{NiCoCrAlY}$ specimen aged at $1150{ }^{\circ} \mathrm{C}$ was polished to remove the first $5 \mu \mathrm{m}$ beneath the oxide/metal interface. Observations in a backscattered electron mode of a large area $\left(8000 \times 2500 \mu \mathrm{m}^{2}\right)$ clearly outlined the heterogeneous distribution of intruded oxides, with millimeter-squared regions exempt of such defects and regions with intruded oxides distant by approx. $150 \mu \mathrm{m}$, as depicted in Figure 8(a). A closer inspection aimed to illustrate the $\beta$-depleted region in the vicinity of the intruded oxides (Figure 8(b)), as for the depleted zone beneath the oxide layer. This "surface" observation of a $\beta$-depleted region in the vicinity of oxides intrusion inside the specimen volume was also confirmed on cross-sectional views (Figure 8(c) through (e)). Element maps obtained by EDX evidenced the Al-depleted/Cr-enriched region surrounding the intruded $\mathrm{Al}_{2} \mathrm{O}_{3}$ oxide. $\mathrm{Ni}$ and $\mathrm{Co}$ element maps were homogeneous on the whole metallic region. This element partitioning is consistent with the $\gamma$ region in the vicinity of the intruded oxides and the $\beta-\gamma$ region in the core of the specimen. 

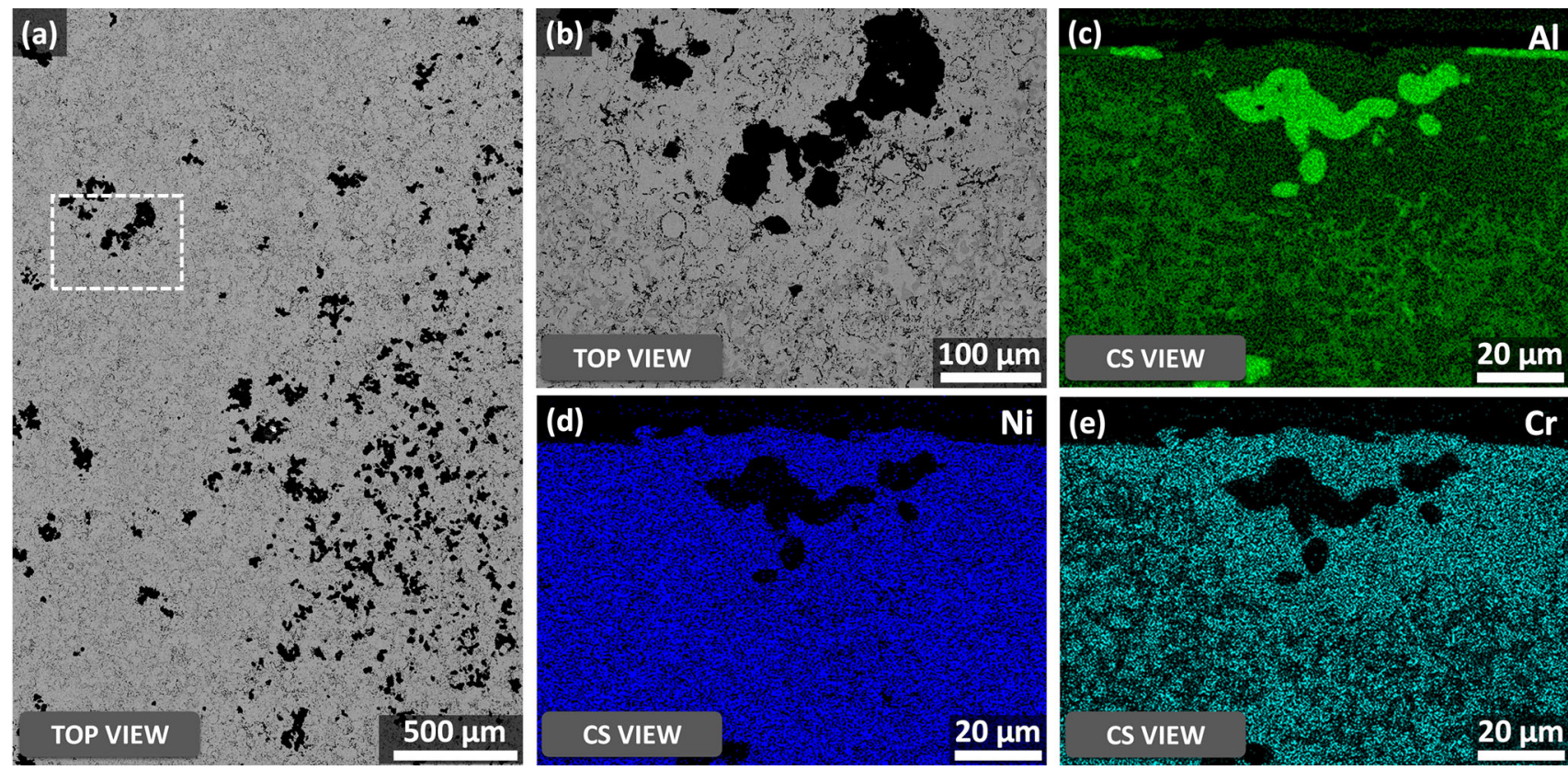

Fig. 8 - Oxide intrusion in NiCoCrAlY APS coatings after high temperature agings at $1150{ }^{\circ} \mathrm{C}-139$ h: $(a)$ Surface observation in backscattered electron mode of a section-plane at $5 \mu \mathrm{m}$ beneath the metal/oxide interface to highlight the heterogeneous distribution of oxide intrusion on a large field of view, $(b)$ Magnification of the region of interest identified with a white dashed box in (a), EDX analyses obtained on a cross-sectional (CS) view for $(c) \mathrm{Al},(d) \mathrm{Ni}$, and (e) Cr element maps showing the extent of the oxide intrusion in depth.

\section{DISCUSSION}

The tensile behavior of the NiCoCrAlY coatings was affected by the aging treatments in two manners, (i) a global evolution of the macroscopic tensile properties below and above $1050{ }^{\circ} \mathrm{C}$ related to microstructure evolutions (see e.g., Sections III-B and III-A), and (ii) a significant variability in the macroscopic tensile properties, especially above $1050{ }^{\circ} \mathrm{C}$ due to oxide intrusion developing in the bulk of the coating with a macroscale distribution. In the following sections, different aspects in terms of testing and preparation conditions, and of microstructure evolutions will be addressed to explain the evolutions of the tensile properties and variability in tensile properties after high temperature aging.

\section{A. Variability in the Tensile Properties for the Aged Coatings}

As far as the preparation and mechanical testing conditions are concerned, the chosen methodology consisted in first machining the microtensile specimens prior to aging treatments, i.e., polishing thin plates of freestanding coating and processing by EDM the shape of the microtensile specimens within the plates. Such microtensile preparation and testing were performed several times at Fraunhofer IWM on various types of materials, brittle or ductile. Low discrepancy in results on the large database of Fraunhofer IWM dismisses the technical preparation and testing of the microtensile specimens as a potential origin of the variability in the mechanical results. Besides, it is worth noting that for A.R. condition, no significant variability was observed for the tested specimens, validating the chosen experimental methodology. This latter information raises the point about microstructural variability introduced when aging specimens on the discrepancy in tensile behavior.

Variability in tensile properties for a given aging condition was found intimately related to the occurrence of defects, such as oxide intrusion in the specimen volume revealed on the fracture surface. The origin of oxide intrusion is worthy of investigations, i.e., from the coating deposition process and/or from specimen preparation. In addition, the use of EDM for micro-specimen machining could introduce some damage or local oxidation. However, for the whole-tested conditions, the failure of specimen was observed within the gage length without clear influence of the edge effect that could have been introduced by EDM. Moreover, defects observed on fracture surfaces driving to premature failure are related to oxide intrusion also observed in solely polished specimens, Figure 8. Therefore, it is believed that the variability in mechanical properties arise from variability in materials, i.e., oxide intrusion affecting the material in the volume, after agings and not from technical reasons.

To the author's knowledge, the origin of oxide intrusion is not documented in the literature but is worthy of investigation to better understand why such variability in mechanical properties. Surface observations of the polished specimens before aging did not reveal particular cracks or crevasses typical of particle pullout. However, intersplat cavities and/or splat interface weakening and/or internal cracks within the coating due to the deposition process might be responsible of the intruded oxide formation. At this stage, it is not possible to discriminate which cause is responsible of such local 
microstructure degradation during aging (oxide intrusion). In addition, the spatial distribution of such oxide intrusion was highly heterogeneous in large regions, explaining the strong variability in macroscopic tensile properties. The intruded oxides are yet similar in both size and morphology for all the aging variants and could contaminate up to 50 pct of the entire specimen cross-section. The relationship between intruded oxides and intersplats needs further investigations.

\section{B. Evolution of the Mechanical Behavior of the Aged Coatings}

How to explain the evolution of mechanical behavior exempt of intruded oxides? First, it has been observed that Young's modulus was increased by aging at $950{ }^{\circ} \mathrm{C}$ and $1050{ }^{\circ} \mathrm{C}$. This point is fully consistent with cross-section observations and fracture surface observations highlighting the presence of an oxide layer adherent to the specimen surface, up to $3.9 \mu \mathrm{m}$ in thickness, even after fracture. The increase in Young's modulus should be partially the consequence of a composite effect, where the oxide Young's modulus, about $400 \mathrm{GPa}$ for pure $\alpha$-alumina, ${ }^{[43]}$ modifies the specimen stiffness. Moreover, the time-temperature conditions has not yielded to significant $\beta-\gamma$ phase transformation, so that the lower Young's modulus of $\gamma$ phase does not impact the global behavior of the material. Finally, the oxide is brittle as compared to the $\beta$ phase, explaining the slight decrease in ductility.

For higher temperature agings, typically $1150{ }^{\circ} \mathrm{C}$, significant $\beta$ to $\gamma$ phase transformation takes place, as reported in Figures 3(d) and 4(c). It has been clearly established that the $\gamma$ phase was more ductile than the $\beta$ phase ${ }^{[13]}$ and that the Young's modulus should decrease with phase transformation. ${ }^{44]}$ The drastic evolution of microstructure has led to an apparent inversion of phase and matrix, so-called topological inversion, for aging conditions at $1150^{\circ} \mathrm{C}$ (Figures 3(d) and 4(c)). However, this effect was only observed for some specimens for which the failure surface exhibited a rather low intrusive oxidation and typical ductile failure mechanisms.

On the other hand, for high temperature agings (above $1050{ }^{\circ} \mathrm{C}$ ), the low ductility specimens were observed for failure surface with pronounced intrusive oxidation with several intruded oxides distributed through the surface (Figures 7(c) and (d)). In association to these intruded oxides, local depletion of Al was observed, as depicted in Figures 7 and 8 . However, even if locally the $\beta$ to $\gamma$ phase transformation was higher, the high ductility of $\gamma$ phase could not balance the oxide (oxide layer and intruded oxide) brittleness due to a rather small-depleted zone as compared to other results in MCrAlY coating. In addition, intruded oxides were not fully adherent to the metal, exhibiting some local debonding features on the fracture surface (Figure 7) and subsequently limiting the ductility. Moreover, for these low ductility specimens, the external oxide layer was not adherent to the metal and led to local oxide spallation. Thus, the composite effect of external oxide does no longer impact neither the stiffness nor the brittle behavior of the specimen as observed for $950{ }^{\circ} \mathrm{C}$ and $1050{ }^{\circ} \mathrm{C}$ aging conditions.

These results show that for high temperature and long-term oxidation, the tested metal failure is driven by intrusive oxidation leading to a ductility function of the intruded oxide volume fraction within the specimen. The fracture surface thus corresponds to the critical gage section of the aged specimens affected by oxide intrusion. Thus, in this respect, the results for high temperature agings appear to be consistent with known results, especially about the beneficial role of $\gamma$ phase in increase of ductility. Besides, for APS overlay coating, intrusive oxidation should be definitively reduced by processing conditions to avoid a drastic decrease in ductility of this kind of coating for thermomechanical stresses.

Complementary studies could validate this set of observations by measuring the intruded oxide volume fraction, instead of surface fraction, to determine critical features in the specimen. Such three-dimensional investigations are possible using X-ray tomography, for instance, where the contrast between oxide and metal is obvious. ${ }^{[45]}$

\section{CONCLUSION}

This paper addressed the influence of high temperature agings on the mechanical behavior of a freestanding MCrAlY coating obtained by APS process. A straightforward methodology was used to obtain the macroscopic tensile properties (Young's modulus, $Y S_{0.05 p c t}$, UTS and STF) combining polishing of the coating and EDM to extract mechanical freestanding coating specimens, then aging. Microtensile testing combined with DIC techniques was performed to determine the effective mechanical properties at room temperature for any aging conditions.

The main results of the present investigation can be summarized as follows:

- the $\beta$ to $\gamma$ phase transformation (coarsening of the two phases, decrease of the $\beta$ phase with the aging temperature, decrease in $\beta$-phase interconnectivity) increases the ductility of the metal and decreases the Young's modulus for agings at $1150{ }^{\circ} \mathrm{C}$;

- in presence of intruded oxidation, the ductility decreases as a function of intruded oxide volume fraction and distribution in the specimen volume;

- external oxide layer could increase the Young's modulus by composite effect and could induce a slight decrease in ductility and an increase in mechanical strength ( $Y S_{0.05 p c t}$ and UTS), especially for agings at $950{ }^{\circ} \mathrm{C}$ and $1050{ }^{\circ} \mathrm{C}$;

- when the external oxide layer is thicker than a critical oxide thickness, typically for $1050{ }^{\circ} \mathrm{C}$ and long exposure or $1150{ }^{\circ} \mathrm{C}$, here above $5 \mu \mathrm{m}$, this oxide layer is no longer adherent to the metal and thus does not influence its behavior. 


\section{ACKNOWLEDGMENTS}

The authors are particularly grateful to René Cluzet for specimen machining, Alain Köster for strain analysis from Centre des Matriaux, and Rémi Roumiguier for help in thin specimen preparation from MIDIVAL. D. Texier would like to thank the Agence Nationale de la Recherche $(A N R)$ for financial support via the ANR-JCJC-COMPAACT project funded from the AAP2018.

\section{CONFLICT OF INTEREST}

The authors declare that they have no conflict of interest.

\section{REFERENCES}

1. J.L. Chaboche and F. Gallerneau: Fatigue Fract. Eng. Mater. Struct., 2001, vol. 24, pp. 405-18.

2. R. Reed: The Superalloys: Fundamentals and Applications, Cambridge University Press, Cambridge, 2008.

3. M. Bensch, C. Konrad, E. Fleischmann, C. Rae, and U. Glatzel: Mater. Sci. Eng. A, 2013, vol. 577, pp. 179-88.

4. R. Mévrel: Mater. Sci. Eng. A, 1989, vols. 120-121, pp. 13-24.

5. T. Rhys-Jones: Corros. Sci., 1989, vol. 29, pp. 623-46.

6. S. Bose: High Temperature Coatings, 1st ed., Butterworth-Heinemann, Oxford, 2007, vol. 81.

7. A. Strang and E. Lang: in High Temperature Alloys for Gas Turbines, R. Brunetaud, D. Coutsouradis, T. Gibbons, Y. Lindblom, D. Meadowcroft, and R. Stickler, eds., Springer, Berlin, 1982, pp. 469-506.

8. K. Schneider and H. Grünling: Thin Solid Films, 1983, vol. 107, pp. 395-416.

9. J. Veys and R. Mévrel: Mater. Sci. Eng., 1988, vol. 88, pp. 253-60.

10. D. Texier: Measurement and Evolution of the Gradient of Mechanical Properties in MCrAlY Coated MC2 Nickel Based Superalloy System. Dissertation, Université de Toulouse, Toulouse, 2013.

11. K. Hemker, B. Mendis, and C. Eberl: Mater. Sci. Eng. A, 2008, vols. $483-484$, pp. $727-30$.

12. D. Texier, D. Monceau, Z. Hervier, and E. Andrieu: Surf. Coat. Technol., 2016, vol. 307, pp. 81-90.

13. D. Texier, D. Monceau, F. Crabos, and E. Andrieu: Surf. Coat. Technol., 2017, vol. 326, pp. 28-36.

14. H. Chen and T. Hyde: Mater. Sci. Eng. A, 2017, vol. 680, pp. 203-09.

15. T. Fiedler, H.-R. Sinning, J. Rösler, and M. Bäker: Surf. Coat. Technol., 2018, vol. 349, pp. 32-36.

16. G. Jackson, W. Sun, and D. McCartney: Mater. Sci. Eng. A, 2019 , vol. 754, pp. 479-90.

17. M. Hebsur and R. Miner: Mater. Sci. Eng., 1986, vol. 83, pp. $239-45$.

18. J. Nicholls: $J O M, 2000$, vol. 52 , pp. 28-35.

19. E. Chataigner and L. Remy: in Thermomechanical Fatigue Behavior of Materials, M. Verrilli and M. Castelli, eds., ASTM International, West Conshohocken, 1996, vol. 2, pp. 3-26.
20. T. Pollock, B. Laux, C. Brundidge, A. Suzuki, and M. He: J. Am. Ceram. Soc., 2011, vol. 94, pp. s136-45.

21. R. Subramanian, Y. Mori, S. Yamagishi, and M. Okazaki: Metall. Mater. Trans. A, 2015, vol. 46A, pp. 3999-4012.

22. P. Sallot, V. Maurel, L. Rémy, F. NGuyen, and A. Longuet: Metall. Mater. Trans. A, 2015, vol. 46A, pp. 4589-4600.

23. MZ. Alam, C. Parlikar, D. Chatterjee, and D.K. Das: Mater. Des., 2017, vol. 114, pp. 505-14.

24. V.A. Esin, V. Maurel, P. Breton, A. Köster, and S. Selezneff: Acta Mater., 2016, vol. 105, pp. 505-18.

25. M. P. Taylor, H.E. Evans, E.P. Busso, and Z.Q. Qian: Acta Mater., 2006, vol. 54, pp. 3241-52.

26. R. Hüttner, J. Gabel, U. Glatzel, and R. Völkl: Mater. Sci. Eng. A, 2009, vols. 510-511, pp. 307-11.

27. M. Eskner and R. Sandstrom: Surf. Coat. Technol., 2003, vol. 165, pp. 71-80.

28. K. Hemker and W. Sharpe: Annu. Rev. Mater. Res., 2007, vol. 37, pp. 93-26.

29. D. Gianola and C. Eberl: JOM, 2009, vol. 61, pp. 24-35.

30. M.Z. Alam, S. Kamat, V. Jayaram, and D. Das: Acta Mater., 2014, vol. 67, pp. 278-96.

31. D. Texier, D. Monceau, JC. Salabura, R. Mainguy, and E. Andrieu: Mater. High Temp., 2016, vol. 33, pp. 325-37.

32. D. Texier, D. Monceau, S. Selezneff, A. Longuet, and E. Andrieu: Metall. Mater. Trans. A, 2020, vol. 51A, pp. 1475-80.

33. S. Saeidi, KT. Voisey, and DG. McCartney: J. Therm. Spray Technol., 2011, vol. 20, pp. 1231-43.

34. D. Pan, M. Chen, P. Wright, and K. Hemker: Acta Mater., 2003, vol. 51, pp. 2205-17.

35. C. Eberl, D. Gianola, and K. Hemker: Exp. Mech., 2010, vol. 50, pp. 85-97.

36. C. Eberl, R. Thomson, D. Gianola, S. Bundschuh: Digital Image Correlation and Tracking - File Exchange-MATLAB Central h ttps://uk.mathworks.com/matlabcentral/fileexchange/50994-digita l-image-correlation-and-tracking, 2010.

37. Praxair Surface Technologies: http://www.praxairsurfacetechnolo gies.com/components-materials-and-equipment/materials/thermal -spray-powders/mcraly, 2019.

38. T. Kennerknecht: Fatigue of Micro Molded MaterialsAluminum Bronze and Yttria Stabilized Zirconia: Ph.D. thesis: Fraunhofer Institut fr Werkstoffmechanik, 2014.

39. SA. Slaby, O. Kraft, and C. Eberl: Fatigue Fract. Eng. Mater. Struct., 2016, vol. 39, pp. 780-89.

40. D. Knetsch, M. Funk, T. Kennerknecht, and C. Eberl: Mater. Test., 2014, vol. 56, pp. 535-41.

41. S. Fliegener, T. Kennerknecht, and M. Kabel: Composites B, 2017, vol. 112 , pp. $327-43$.

42. J. Schindelin, I. Arganda-Carreras, E. Frise, V. Kaynig, M. Longair, T. Pietzsch, S. Preibisch, C. Rueden, S. Saalfeld, B. Schmid, J.-Y. Tinevez, D. James White, V. Hartenstein, K. Eliceiri, P. Tomancak, and A. Cardona: Nat. Methods, 2012, vol. 9, pp. 676-82.

43. M. Fukuhara and I. Yamauchi: J. Mater. Sci., 1993, vol. 28, pp. 4681-88.

44. N. Rusović and H. Warlimont: Phys. Status Solid. A, 1979, vol. 53, pp. 283-88.

45. V. Maurel, L. Helfen, R. Soulignac, TF. Morgeneyer, A. Koster, and L. Rémy: Oxid. Met., 2013, vol. 79, pp. 313-23. 